\title{
Structure and dynamics of benthic megafauna on the continental shelf offshore of Ubatuba, southeastern Brazil
}

\author{
Ana Maria Setubal Pires \\ University of Sảo Paulo, Institute of Oceanography, CP 9075, 01000 São Paulo, Brazil
}

\begin{abstract}
Twelve survey cruises on the continental shelf offshore of Ubatuba, southeastern Brazil, were conducted during 1985 to 1987 as a part of a broad oceanographic investigation on the tropical Atlantic shelf ecosystem. Two different water masses influence the seabed: South Atlantic Central Water (SACW) and Coastal Water ( $\mathrm{CW}$ ). The first penetrates towards the coast during summer months, and retreats offshore in the winter. Distribution, density and biomass of the benthic megafauna show 2 domains: inner shelf and outer shelf, both separated by a front. High abundance of the brachyuran crab Portunus spinicarpus characterizes the frontal system and occasionally changes the structure of the inner and outer shelf assemblages. Multivariate analyses showed that water masses and sea depth are the main factors structuring the benthic megafauna communities. Clustering analysis disclosed 4 distinct faunistic assemblages: (1) coastal communities within the $\mathrm{CW}$ domain, (2) inner shelf communities influenced by a mixed zone with $\mathrm{CW}$ predominant, (3) frontal zone communities where SACW was predominant, (4) outer shelf communities within the SACW domain. Species diversity was almost homogeneous on the entire shelf except in the frontal zone where it sharply decreased. The common species, both perenial and seasonal, showed a consistent pattern of dominance through the study period. Adjustments occur within the community whereby some species increase in abundance when others decrease, maintaining a stable pattern. A 'cyclic' stability-adjustment mechanism is proposed to explain the dynamics of the megabenthos in the Ubatuba region.
\end{abstract}

\section{INTRODUCTION}

Studies of continental shelf ecosystems began nearly 50 yr ago. Since then, much effort has been spent in describing benthic assemblages. In recent years interest in dynamic processes within benthic communities has developed, mainly for temperate and high-latitude regions. In these ecosystems the spatial patterns of the communities are well known (e.g. Hughes et al. 1972, Maurer \& Leathem 1980, Grebmeier et al. 1988, 1989). In contrast, tropical shelf ecosystems are less understood despite their quantitative significance - they comprise nearly one-third of the sea shelf. As pointed out by Wiebe (1987), tropical marine systems have been inadequately studied and frequently sampled at only a few sites by short-term expeditions.

The present study was a part of a broader interdisciplinary research program designed to understand the structure and function of a tropical coastal ecosystem in
Ubatuba, southeastern Brazil. A particularly important aspect of the area investigated is its hydrographic structure. Three water masses are present on the shelf with different distributional patterns in summer and winter. Coastal Water (CW) has a high temperature and low salinity $\left(T>20^{\circ} \mathrm{C}, S<36.0 \%\right.$ ), Tropical Water (TW) has both a high temperature and salinity $\left(T>20^{\circ} \mathrm{C}, S>36.0 \%\right)$, and South Atlantic Central Water (SACW) shows both low temperature and salinity $\left(T<18{ }^{\circ} \mathrm{C}, S<36.0 \%\right.$ ) (Castro Filho et al. 1987).

During austral summer the SACW strongly penetrates into the bottom layer of the coastal region and forms a strong thermocline in midwater. By winter, the SACW retreats to the shelf break and is replaced by CW. As a result, no stratification is present over the inner shelf in winter months. To complete the hydrological structure of the area frontal eddies occur in both seasons on the outer shelf.

The SACW is rich in nutrients $(\mathrm{N}$ and $\mathrm{P})$ and, when it 
reaches shallow areas in summer, promotes intense eutrophication, which increases the local primary production by 7 to 10 times (E. Aidar, Instituto Oceanográfico da U.S.P., pers. comm.). Consequently, more food should be channeled to the benthos in summer, resulting in a seasonal variation in its biomass.

Knowledge of the dynamics of the couplings between the benthic subsystem and hydrography of a region, together with the nutrient load of the water, is crucial to our understanding of the structure and function of shelf systems (Longhurst 1978, Smetacek 1984, Soberón-Chávez et al. 1988).

The benthic megafauna from the Ubatuba region had received little attention until the present investigation, even though the inner shelf has been subjected to intensive trawling for penaeid shrimps since 1965 (Neiva 1969). Sartor (1990) and Petti (1990) were the only authors to present detailed studies on distribution and feeding habits of brachyuran crabs, respectively. The present report describes the species composition, structure and variability of the soft-bottom megafauna over the continental shelf in Ubatuba, and explains the occurrence and maintenance of the megafauna communities in relation to the dynamic interactions among several biotic and abiotic components present in the system.

\section{MATERIAL AND METHODS}

Megafauna communities were sampled at 18 sites located between 10 and $120 \mathrm{~m}$ depth over the continental shelf off Ubatuba in the southeastern Brazilian Bight (Fig. 1). Sampling was carried out seasonally on the inner shelf (10 to $50 \mathrm{~m}$ depth, Sites 1 to 9 ) with the research trawler 'Veliger II' and biannually (summer and winter) on the outer shelf (50 to $100 \mathrm{~m}$ depth, Sites 10 to 18 ) with the RV 'Prof. W. Besnard', of the University of São Paulo. A total of 12 survey cruises were performed from October 1985 to July 1987, obtaining 108 samples.

The benthic fauna was collected with otter trawl bottom nets of 20 and $24 \mathrm{~mm}$ mesh-size having, respectively, 6 and $9 \mathrm{~m}$ mouth width when expanded. The smaller net was employed on board the 'Veliger II' and the other on board the 'Prof. W. Besnard'. The performance of the 2 nets was compared by trawling them simultaneously 3 times at the same place. As the catches showed no significant qualitative or quantitative differences, it was assumed that both nets were equally efficient. The areas trawled by the nets were $22236 \mathrm{~m}^{2}$ for the smaller and $33354 \mathrm{~m}^{2}$ for the larger one. The nets were towed at $6 \mathrm{~km} \mathrm{~h}^{-1}$ over the bottom, perpendicular to the coast, at the stations shown in Fig. 1, for $60 \mathrm{~min}$. A total of $108 \mathrm{trawls}$ (unity samples) were

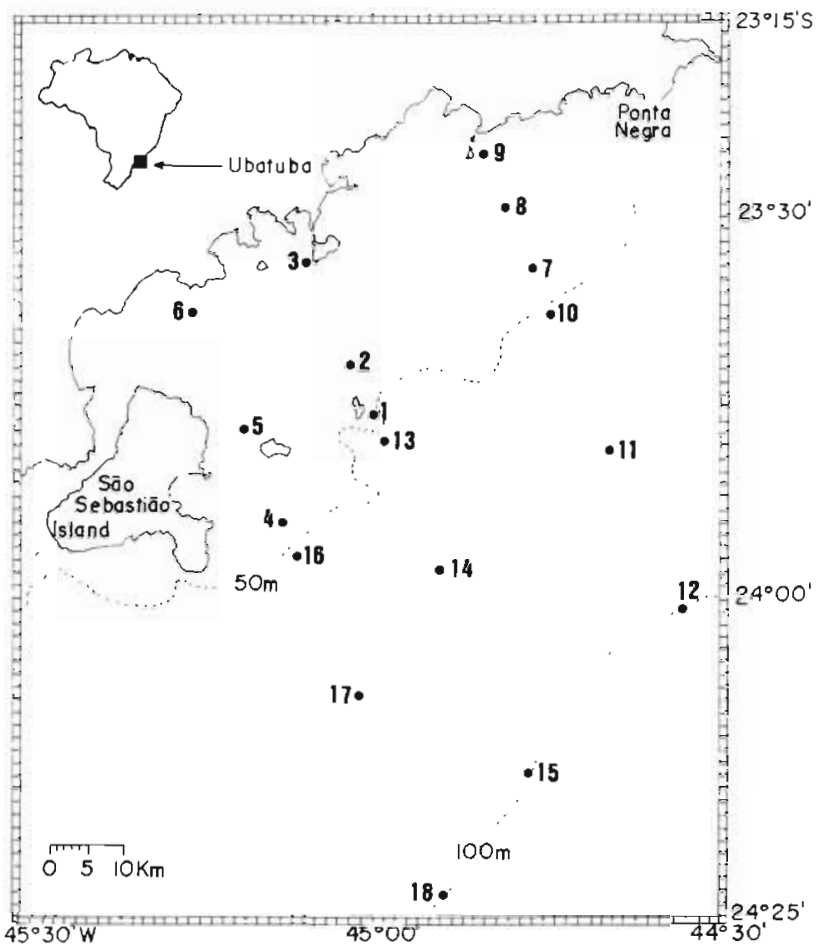

Fig. 1. Study area in the southern Brazilian shelf showing sampling stations ( 1 to 18 ) and bathymetry

completed, 72 for the inner shelf and 36 for the outer shelf. Each sample was numbered according to its original site ( 1 to 18 ) plus a letter indicating the season of the year when it was obtained (e.g., $1 \mathrm{P}=$ Site 1 , spring; $1 \mathrm{~S}=$ Site 1 , Summer). Upon retrieval, the invertebrates from each catch were frozen in plastic bags. When the number of animals exceeded several hundred, 300 specimens were sub-sampled at random from the catch.

In the coastal laboratory organisms were identified to species level for most taxonomic groups (except for Porifera), counted and weighed (wet weight, mollusc shells included). Data for each species were standardized for both nets and are expressed as number of individuals per area of trawling (33 $\left.354 \mathrm{~m}^{2}\right)$ and number and wet weight of individuals per $\mathrm{m}^{2}$. Temperature, salinity and bottom water oxygen concentration were measured and sediment was collected at each sample unit. The oxygen saturation level was calculated based on oxygen concentration data (Riley 1971, UNESCO 1973).

Sediment samples were obtained with a $0.1 \mathrm{~m}^{2}$ van Veen grab for textural analysis. Grain size was determined using sieving and pipetting techniques (Suguio 1973). Folk and Ward parameters (Folk \& Ward 1957) and a Shepard triangular diagram (Shepard 1954) were obtained for granulometric classification. The quantity of carbonates and total sedimentary 
organic matter in the sediment was measured by acid dissolution and oxidation on $\mathrm{H}_{2} \mathrm{O}_{2}$, respectively (Gross 1971).

To obtain a general distribution of sediment variables (mean diameter, percent of sand, clay and organic matter) we employed surface trend analysis (Fúlfaro \& Amaral 1970, Landim 1988). A microcomputer statistical program written by P. M. Landim (Universidade Estadual Paulista) was used.

A total of 195 species was obtained. In order to bring the database to a more workable size, the initial data matrix (54 station-points $\times 195$ species) was reduced by eliminating species if less than 2 individuals per sampled period were collected (Jackson 1972). The resulting matrices $(54 \times 39$ and $54 \times 45$ for the first and second years of study, respectively) were analysed after the $\log$ transformations of abundance data, $y=$ $\ln (x+1)$ (Cassie \& Michael 1968). Principal component analysis (PCA), stepwise multiple linear regression (SMLR) and cluster analysis (Q-mode and R-mode) were then employed to identify and interpret the spatial and temporal changes presented by the megafauna. The BMDP statistical package was used in a Burroughs 7400 computer. Cluster R-mode considered the average linkage measure for similarity between species based on their distributions. Cluster Q-mode grouped stations based on the similarities of faunal composition using the weighted pair-group method (Davis 1973) and Morisita's similarity coefficient. Shannon's diversity index $\left(H^{\prime}\right)$ and evenness $(J)$ were calculated for each sample using naperian logarithms ( $\left.\log _{e}\right)$.

\section{RESULTS}

\section{Physical environment}

Nine physical parameters were analysed for the area studied: depth, temperature, salinity, dissolved oxygen, organic matter, carbonates, median diameter of sediment, sand content and clay content.

$\mathrm{T}$-S diagrams (temperature and salinity) verified the presence of 2 water masses near the bottom: Coastal Water and South Atlantic Central Water (Fig. 2). These water masses interact, forming a mixing zone variable in time and space according to the range of SACW penetration. Maximum summer temperature observed was $25.7^{\circ} \mathrm{C}$ and minimum winter temperature was $14.1^{\circ} \mathrm{C}$, both values in the first year. A third water mass, Tropical Water, occurs on the upper layer of the outer shelf, without interacting with the bottom stratum.

SACW penetration has a strong influence on the sea temperature near the bottom. This influence is stronger on the inner shelf in summer months. Here the differ- ence between maximum and minimum temperature values was $11.6^{\circ} \mathrm{C}$ for the first year and $10.5^{\circ} \mathrm{C}$ for the second year.

The results also show a seasonal thermal gradient perpendicular to the coast, very conspicuous in autumn. The northernmost part (Stn 7) was the coldest except in summer, when SACW flows over the inner shelf (Fig. 3). Salinity showed small variation (34.96 to $35.93 \%$ ) and lower values were found near the coast. Oxygen saturation varied from 42 to $111 \%$ but was frequently over $70 \%$. The inner shelf values showed higher variation, encompassing all the oversaturated values. The outer shelf was more stable, with $3 / 4$ of the values near $75 \%$.

A heterogeneous sediment texture is present in the area. There is, however, a general pattern of mean particle size distribution (Fig. 4). The fine-grain fraction (silt) deposits are in 2 areas. The first is situated south of the region, from the coast to near $70 \mathrm{~m}$ depth; the second area is centrally placed, close to the $100 \mathrm{~m}$ isobath. Very fine sand occupies most of the remaining sites. Coarser-grained sand is deposited both near the shelf break (fine sand) and northward of the area (medium sand). The northern part of the area, from the coast to $75 \mathrm{~m}$ depth, has well-sorted sands, i.e. almost all grains of each type of sand are of the same dimension.

\section{Megafauna}

From the 108 trawls completed, 195 species were obtained. Crustacea (Brachyura, Dendrobranchiata, Caridea, Anomura and Stomatopoda) were the most diverse group, with 75 species $(38.5 \%)$. Mollusca followed with 64 species $(33 \%)$, Echinodermata with 30 $(15.5 \%)$, Polychaeta with $20(10 \%)$, Cnidaria with 3 $(1.5 \%)$ and Ascidiacea with 3 (1.5\%). In all, 99664 specimens were sampled from an area of $33354 \mathrm{~m}^{2}$, in 108 hauls. Two species, Portunus spinicarpus (Brachyura, Portunidae) and Xiphopenaeus kroyeri (Dendrobranchiata, Penaeidae), contributed $67 \%$ to the total number of specimens, while all the others represented individually less than $3.1 \%$ (Table 1). P. spinicarpus and $X$. kroyeri were the main contributors to biomass, with about $43 \%$ of total wet weight (Table 2).

The most frequently occurring species are shown in Table 1. Of these species, 39 occurred during 1985-86, and 45 during 1986-87.

Species distribution also reflected the different features of the inner shelf. A higher number of species tolerant to low temperatures was found on the northern shelf. Here, the most abundant species were Luidia ludwig scotti, Siratus tenuivaricosus, Zidona dufresnei, Leurocyclus tuberculosus and Portunus spinicarpus, 
A
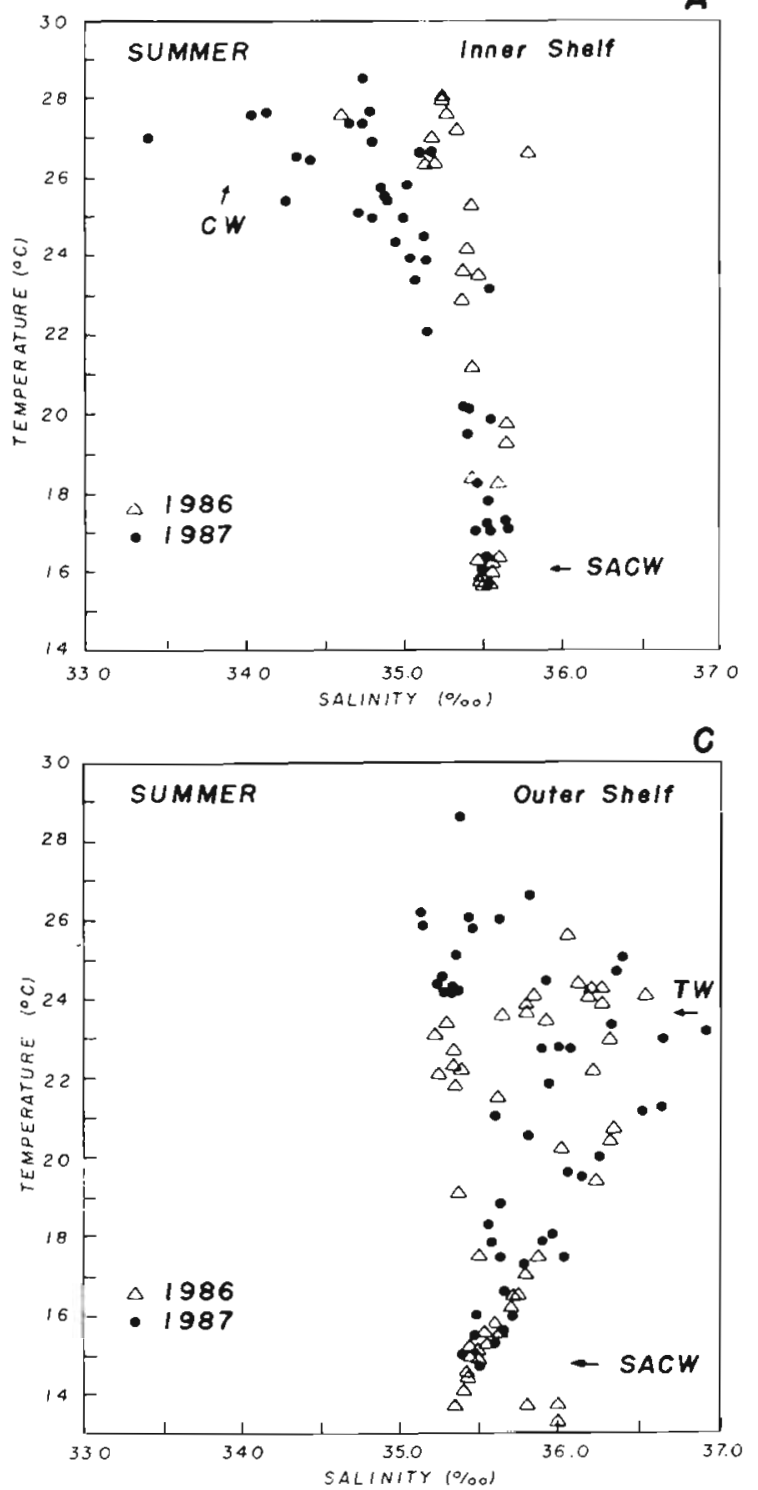
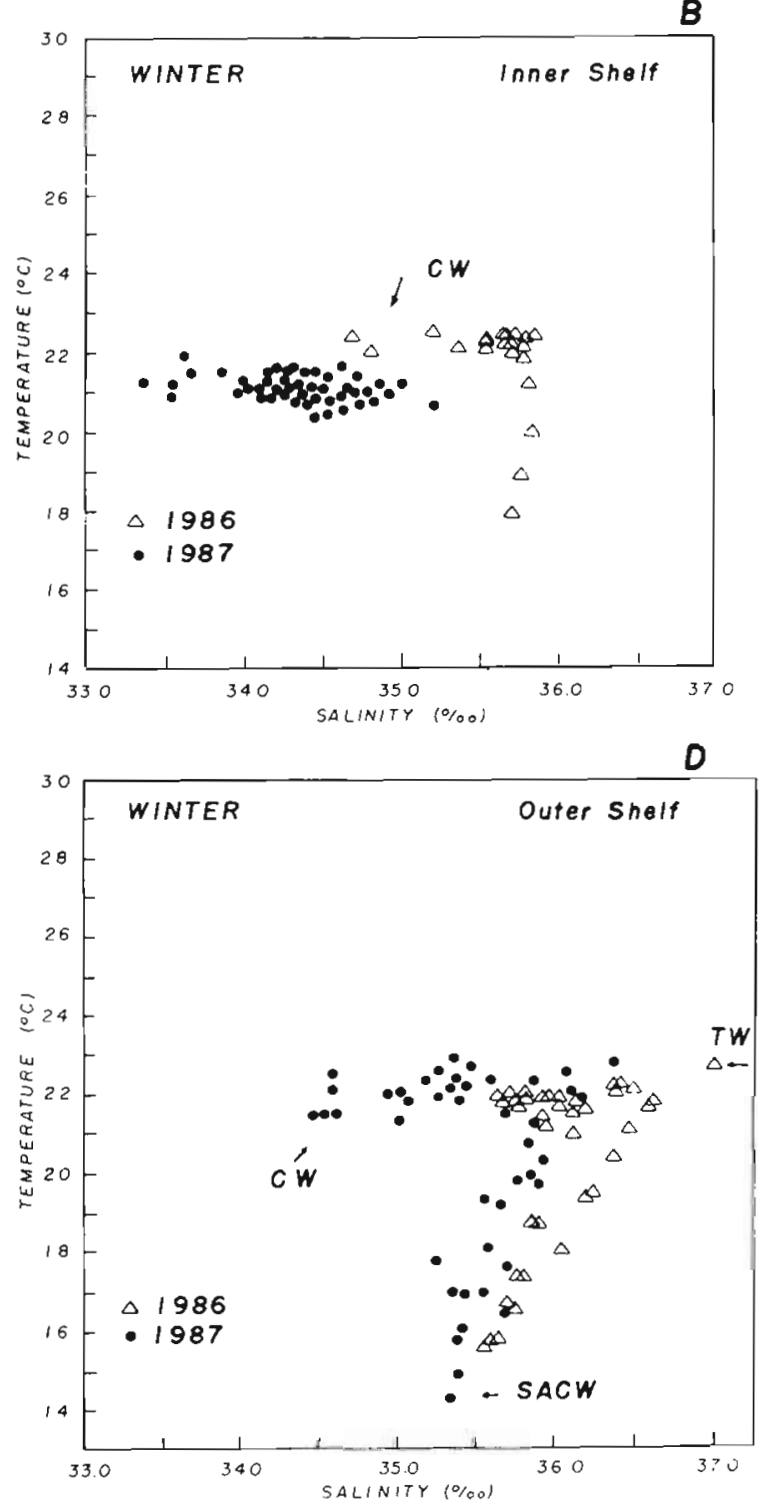

Fig. 2. T-S diagram showing temperature and salinity pairs, sampled during summer and winter near the bottom of the (A, B) inner shelf and (C, D) outer shelf. CW: Coastal Water; SACW: South Atlantic Central Water; TW: Tropical Water

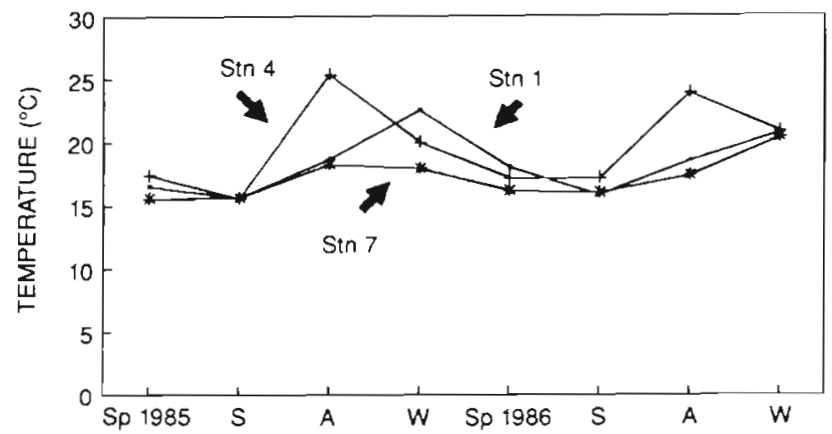

Fig. 3. Latitudinal variation in temperature during the sampling period on the inner shelf. Sp: Spring; S: summer; A: autumn; W: winter which are common on sandy bottoms with water colder than $17^{\circ} \mathrm{C}$ (Williams 1984, Rios 1985, Bordin 1987).

The mid-southern area contained a higher number of species with tropical affinities: Luidia senegalensis, Astropecten marginatus, Buccinanops gradatum, Pleoticus mulleri, Artemesia longinaris and Penaeus schimitti. Although these warm-water species were present at some places on the outer shelf, they were more abundant on the central and southern inner shelf. where Coastal Water predominated.

There were seasonal and inter-annual fluctuations in megafauna abundance and biomass (Table 3). Abundance was 1.3 times higher in summer than winter in 1985-86. However, in 1986-87 this parameter 


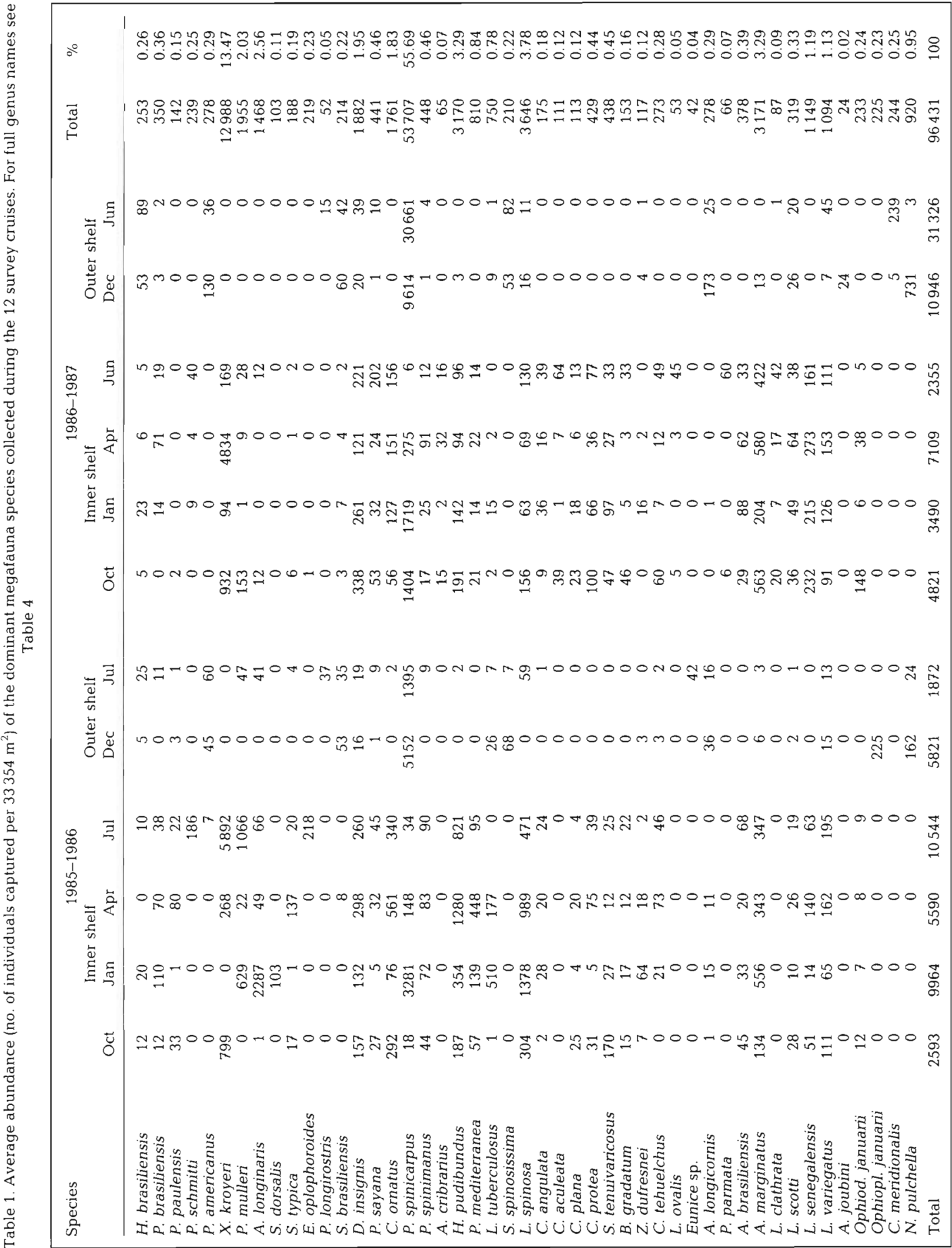




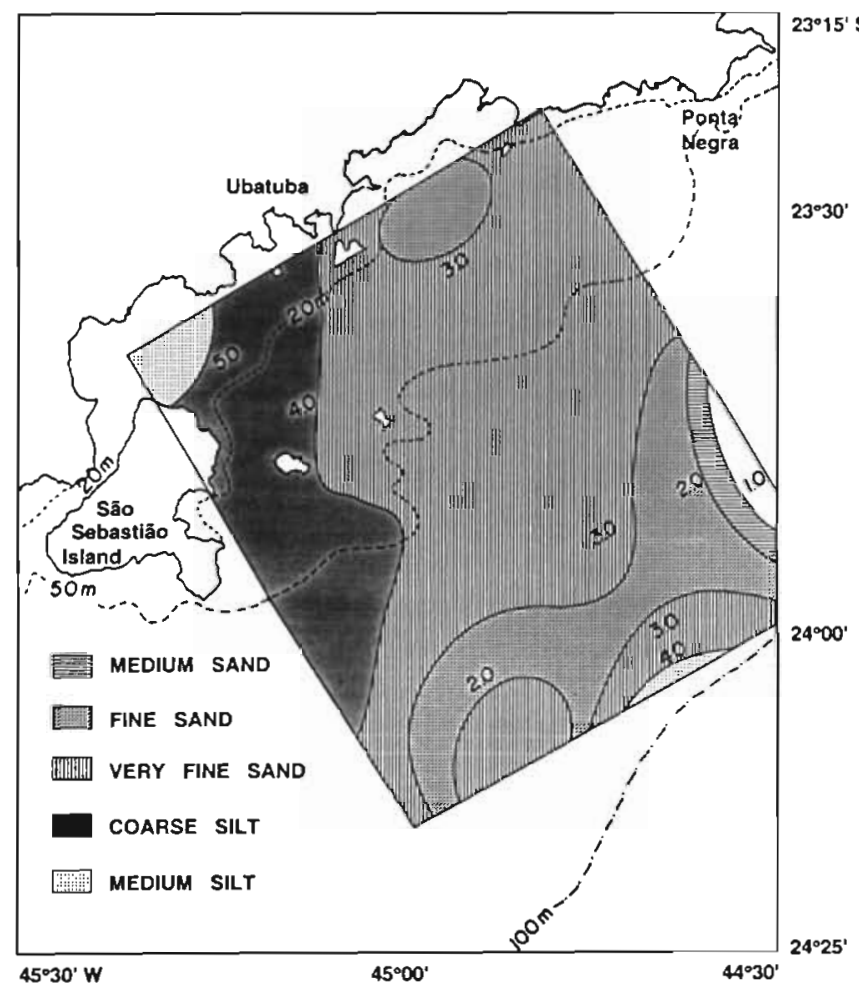

Fig. 4. Distribution of sediment grain sizes $(\phi)$ in the studied area, according to surface trend analysis for the 4 th degree

increased sharply in winter, reaching values about 2.3 times higher than in summer. Biomass followed the same distribution as abundance for both periods.

Abundance and biomass also displayed a spatial difference. In 1985-86 the megafauna was nearly 3.6 times more abundant and had nearly 4.5 more biomass on the inner than the outer shelf. In contrast, during $1986-87$ higher values of abundance and biomass were found on the outer shelf.

Regarding seasonal fluctuations in abundance during the first year, peaks occurred in summer and winter on the inner shelf and in summer on the outer one (Table 3). Higher coastal values in summer reflected the presence of the decapods Artemesia longinaris, Portunus spinicarpus and Libinia spinosa. The winter values were mainly attributable to the shrimps Xiphopenaeus kroyeri and Pleoticus mulleri. On the outer shelf Portunus spinicarpus was the major species responsible for the summer abundance values (Table 1). For the second year fluctuations on the inner shelf were smaller, with an autumn peak attributed mainly to $X$. kroyeri. Conversely a high abundance value was present in winter on the outer shelf. The striking winter increase was due to $P$. spinicarpus, which was present in large numbers at Stns 15 and 18.

\section{Spatial and temporal distribution of faunal assemblages}

Principal component analysis was applied to the megabenthos abundance data from the first year of the study. Coordinates (loadings) of the first 4 components accounted for $49.11 \%$ of the variance and axis I and II corresponded to $35.6 \%$. High positive loadings on axis I $(23.06 \%$ of the total variance) corresponded to high mean densities of Astropecten brasiliensis, Persephona mediterranea, Dardanus arrosor insignis, Hepatus pudibundus and Callinectes ornatus (Fig. 5A) (see Table 4 for taxa code references).

Axis I clearly separates shallow and warm samples on the inner shelf (with highest positive scores) from deeper and colder samples on the outer shelf (with highest negative scores) (Fig. 5B). This last group also encompasses few sites from the central and northern part of the inner shelf, in springtime.

Factor scores for the first axis were related to several environmental variables according to the stepwise multiple linear regression employed. The fitted model indicates that $63.7 \%$ of the variation in factor scores is explained by 3 variables which presented significant $t$ values (Table 5). The variable most highly correlated

Table 2. Total biomass (wet weight in $\mathrm{g} \mathrm{m}^{-2}$, considering 9 hauls per sampled period) of Xiphopenaeus kroyeri, Portunus spinicarpus and all megafauna species collected during the survey cruises

\begin{tabular}{|c|c|c|c|c|c|c|c|c|}
\hline \multirow[t]{2}{*}{ Species } & \multicolumn{4}{|c|}{ Inner shelf } & \multicolumn{2}{|c|}{ Outer shelf } & \multirow[t]{2}{*}{ Total } & \multirow[t]{2}{*}{$\%$} \\
\hline & Oct 1985 & $\operatorname{Jan} 1986$ & Apr 1986 & Jul 1986 & Dec 1985 & Jul 1986 & & \\
\hline X. kroyeri & 0.07 & 0.00 & 0.05 & 1.08 & 0.00 & 0.00 & 1.2 & 4.76 \\
\hline P. spinicarpus & 0.00 & 1.67 & 0.04 & 0.01 & 3.38 & 0.31 & 5.41 & 21.46 \\
\hline \multirow[t]{2}{*}{ All species } & 2.84 & 5.89 & 6.20 & 5.66 & 3.61 & 1.01 & 25.21 & 100 \\
\hline & Oct 1986 & $\operatorname{Jan} 1987$ & Apr 1987 & Jul 1987 & Dec 1986 & Jul 1987 & & \\
\hline X. kroyeri & 0.18 & 0.03 & 0.98 & 0.04 & 0.00 & 0.00 & 1.23 & 4.37 \\
\hline P. spinicarpus & 0.92 & 1.24 & 0.25 & 0.00 & 3.06 & 10.26 & 15.73 & 55.92 \\
\hline All species & 3.43 & 3.18 & 3.44 & 2.36 & 4.03 & 11.69 & 28.13 & 100 \\
\hline
\end{tabular}


Table 3. Number of individuals per 9 trawls $(\mathrm{n})$, density $\left(\mathrm{D}, 10 \times\right.$ no. $\left.\mathrm{m}^{-2}\right)$ and biomass $\left(\mathrm{B}, \mathrm{g} \mathrm{m}^{-2}\right)$ of the benthic megafauna

\begin{tabular}{|c|c|c|c|c|c|c|}
\hline & \multicolumn{3}{|c|}{ Inner shelf } & \multicolumn{3}{|c|}{ Outer shelf } \\
\hline & $\mathrm{n}$ & $\mathrm{D}$ & B & $\mathrm{n}$ & $\mathrm{D}$ & B \\
\hline \multicolumn{7}{|l|}{ 1985-1986 } \\
\hline Spring & 2853 & 12.83 & 2.84 & & & \\
\hline Summer & 10212 & 45.93 & 5.89 & 6034 & 27.13 & 3.61 \\
\hline Autumn & 5749 & 25.85 & 6.2 & & & \\
\hline Winter & 10790 & 48.52 & 5.66 & 2184 & 9.82 & 1.01 \\
\hline Total & 29604 & 133.13 & 20.59 & 8218 & 36.95 & 4.62 \\
\hline \multicolumn{7}{|l|}{$1986-1987$} \\
\hline Spring & 5296 & 23.82 & 3.43 & & & \\
\hline Summer & 3627 & 16.31 & 3.18 & 11331 & 50.9 & 4.03 \\
\hline Autumn & 7222 & 32.48 & 3.44 & & & \\
\hline Winter & 2750 & 12.37 & 2.36 & 31616 & 142.18 & 11.69 \\
\hline Total & 18895 & 84.97 & 12.41 & 42947 & 193.08 & 15.72 \\
\hline
\end{tabular}

with axis I is depth, followed by temperature and clay. Depth and clay are inversely related with axis I scores. Axis I also separates deeper places with a high amount of fine sediment from medium depths $(30$ to $40 \mathrm{~m})$ with coarser sediments.

In summary, axis I isolates species abundant in shallow depths at high temperatures from those species abundant in deeper water at low temperatures.

Axis II corresponds to $12.5 \%$ of the total variance. The variance explained by each factor is the eigenvalue for that factor. High positive loadings on axis II corresponded to high densities of Xiphopenaeus kroyeri, Buccinanops gradatum, Astropecten marginatus, Luidia senegalensis. High negative loadings are related to a high abundance of Hemisquilla braziliensis, Crepidula protea, Siratus tenuivaricosus and Zidona dufresnei (Fig. 5A).

Axis II separates samples on the inner shelf. The warmer $\left(>23^{\circ} \mathrm{C}\right.$ ) and shallower $(15$ to $20 \mathrm{~m}$ ) samples had higher positive scores on axis II and the colder $\left(15.3\right.$ to $15.7^{\circ} \mathrm{C}$ ) and deeper ( 35 to $45 \mathrm{~m}$ ) ones presented higher negative scores (Fig. 5B).

Table 5 shows the environmental variables most closely related to axis II scores. $32.6 \%$ of the variation in axis II is explained by 2 variables. The variable most highly correlated is temperature, followed by sand content; the latter variable is inversely related to the scores. Axis II isolates species associated with high temperatures and muddy sediments from species characteristic of lower temperatures and sandy bottoms. Spatially it separates the southern muddy and warm inner shelf from the northern sandy and colder inner shelf.

Cluster analysis was employed for grouping sample unities (Q-mode) and species (R-mode). For the first year of the study the dendrogram of similarities among sample unities shows 4 main groups (Fig. 6A) directly related with both the presence of water masses and depth, i.e. with axis I of the principal component analysis. The first branching of the dendrogram clearly discriminates the samples under SACW dominance. The second branch groups samples in the CW domain, which form Groups 2 to 4 of the dendrogram. Group 2 contains samples exclusively in the $\mathrm{CW}$ domain and is dominated by Xiphopenaeus kroyeri, Astropecten marginatus and Callinectes ornatus. Group 3 contains samples influenced by mixing warm waters and is dominated by Hepatus pudibundus and Libinia spinosa. Finally a fourth cluster encompasses sites within the mixing cold water domain, with Leurocyclus tuberculosus and Litechinus variegatus dominant (see Fig. 2 for the distribution of water masses).

The first group corresponds to the whole outer shelf and includes a few summer stations of the inner shelf. The second group includes the shallower and warmer samples and the third group corresponds to inner shelf stations, mainly in autumn and winter, plus boundary sites situated on the outer shelf in the winter. Finally the fourth group is related to the inner shelf samples in spring and summer. Each group of stations is dominated by characteristic species (Fig. 6A).

The dendogram of similarities among species (Fig. $7 \mathrm{~A})$ shows 3 main groups. The first contains species occurring up to $75 \mathrm{~m}$ depth, under SACW influence during most of the year. This group encompasses 2 sub-groups: one with species distributed around $75 \mathrm{~m}$ depth (Scyllarides brasiliensis, Eunice sp., Aphrodita longicornis and Ophioplocus januarii), the other with species at about $100 \mathrm{~m}$ depth (Parapenaeus americanus, Stenocionops spinosissima and Neocomatella pulchella).

Warm-water species form the second group, which is 

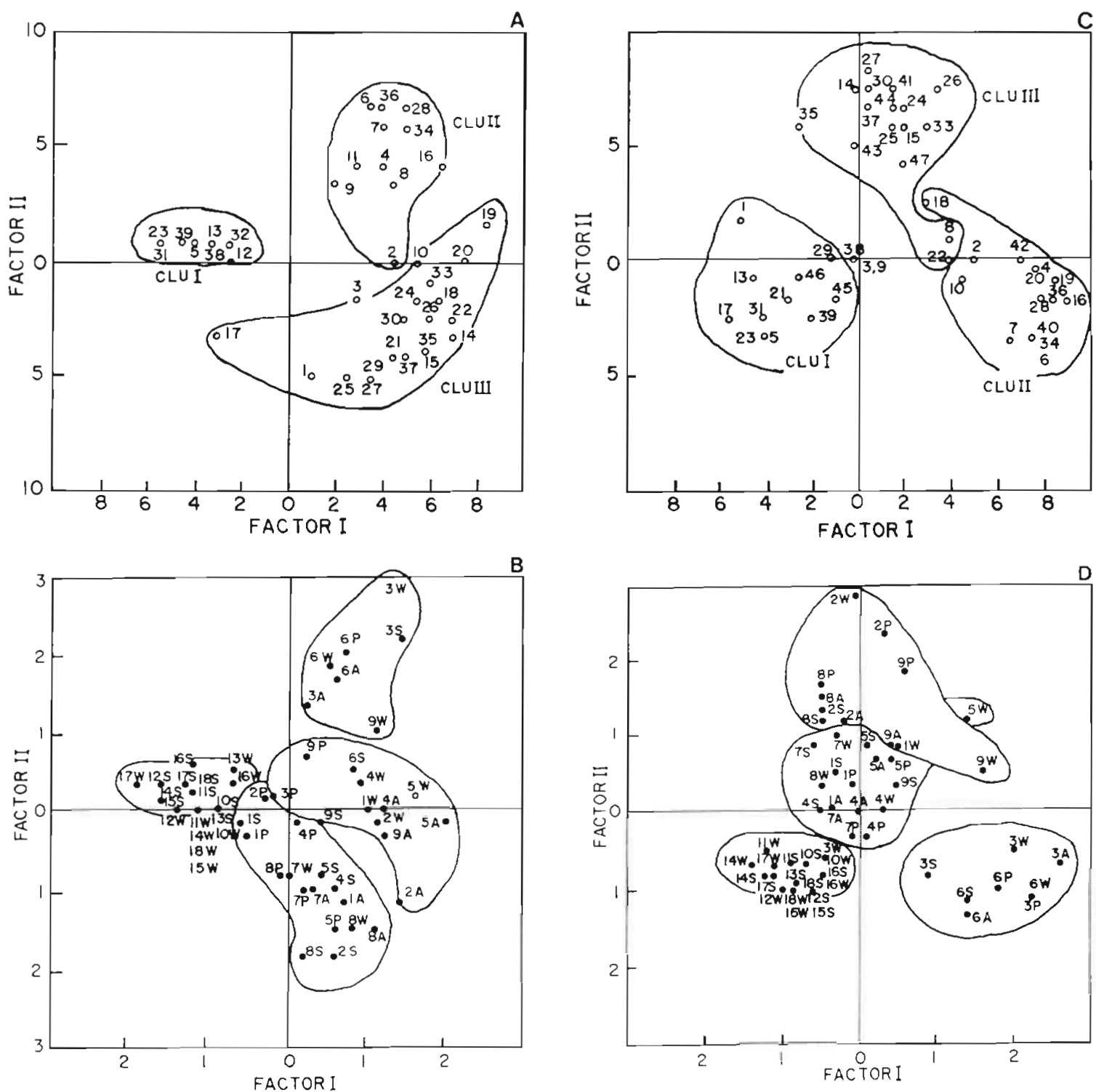

Fig. 5. Principal component analysis for $(A, B)$ the first and $(C, D)$ second year of the study. Distributions of species (A, C) and sample unities $(B, D)$ are shown as a function of the first 2 axes. Species code numbers are shown in Table 4

under the permanent influence of Coastal Water. Astropecten marginatus and Buccinanops gradatum are typical of this group. Sediment type (sandy, muddy and mixed bottom) defines sub-groups. Muddy and mixed bottoms are dominated by Xiphopenaeus kroyeri in winter and by Astropecten marginatus and Callinectes ornatus in the other seasons. Associated species are Penaeus schimitti, Pleoticus mulleri, Exhippolysmata oplophoroides, and Luidia senegalensis. On the other hand, sandy bottoms are occupied mainly by the shrimps Penaeus brasiliensis, Artemesia longinaris and Sicyonia dorsalis.

Finally the third and largest group contains species living between 20 and $70 \mathrm{~m}$ depth under the influence of the mixing water zone. Here 2 sub-groups exist. The first is primarily influenced by $\mathrm{CW}$ and corresponds to the innermost shelf. The second is primarily influenced by SACW and corresponds to the intermediate shelf. Libinia spinosa is typical of first group, Litechinus variegatus of the second.

The same analyses (PCA, SMLR and cluster) were carried out with the second year data set. The results were basically the same as those of the first year, strengthening the interpretation of the results (Figs. 6B \& $7 \mathrm{~B}$, Table 5).

There was little variation with respect to species composition in the 2 years of data. The bulk of the species remained in the same ecological group 
Table 4. Species included in pricipal component analysis and cluster analysis, with their respective code numbers

\begin{tabular}{|l}
1 Hemisquilla brasiliensis \\
2 Penaeus brasiliensis \\
3 Penaeus paulensis \\
4 Penaeus schmitti \\
5 Parapenaeus amencanus \\
6 Xiphopenaeus kroyeri \\
7 Pleoticus mulleri \\
8 Artemesia longinaris \\
9 Sycionia dorsalis \\
10 Sycionia typica \\
11 Exhippolysmata oplophoroides \\
12 Plesionika longirostris \\
13 Scyllarides brasiliensis \\
14 Dardanus arrosor insignis \\
15 Porcellana sayana \\
16 Callinectes ornatus \\
17 Portunus spinicarpus \\
18 Portunus spinimanus \\
19 Hepatus pudibundus \\
20 Persephona mediterranea \\
21 Leurociclus tuberculosus \\
22 Libinia spinosa \\
23 Stenocionops spinosissima \\
24 Chaetopleura angulata \\
25 Crepidula protea \\
26 Crepidula plana \\
27 Siratus tenuivaricosus \\
28 Buccinanops gradatum \\
29 Zidona dufresnei \\
30 Chlamys tehuelchus \\
31 Aphrodita longicornis \\
32 Eunice sp. \\
33 Astropecten brasiliensis \\
34 Astropecten marginatus \\
35 Luidia ludwigi scotti \\
36 Luidia senegalensis \\
37 Litechinus variegatus \\
38 Ophioplocus januarii \\
39 Neocomatella pulchella \\
40 Aranaeus cribrarius \\
41 Crepidula aculeata \\
42 Lunarca ovalis \\
43 Pherusa parmata \\
44 Luidia clathrata \\
45 Amphiura joubini \\
46 Comactinia meridionalis \\
47 Ophioderma januarii \\
\end{tabular}

throughout the study period. However, the limits of the groups were not fixed. Some species placed in the large mixing zone in one year could occur in $\mathrm{CW}$ or SACW zones in the other year, depending on their temperature preference. Sicyonia typica, Callinectes ornatus, Portunus spinimanus and Persephona mediterranea illustrate the first case (mixing zone to $\mathrm{CW}$ ), Leurocyclus tuberculosus and Hemisquilla brasiliensis the latter (mixing zone to SACW) (Fig. 7).

\section{Structure of the benthic megafauna}

Mean diversity and mean evenness were calculated for the 4 assemblages defined by cluster analysis. Values were almost homogeneous on the inner and outer shelf but significantly lower on the frontal zone (Table 6).

The low value of average diversity from the frontal zone was tested using a Mann-Whitney $U$-test (Siegel 1956). For the first year of the study comparison between the values of the frontal zone and those of the SACW zone showed $U=11$ for $\mathrm{p}=0.01$, indicating that mean diversity was significantly lower on the frontal zone. A comparison was also made between the frontal zone and the contiguous mixed zone dominated by CW. The analysis showed $U=1$ for $\mathrm{p}=0.0001$, indicating a significantly lower mean diversity for the frontal zone.

For the second year of the study the results were similar, thus pointing out that the frontal zone is significantly different from the other zones considered (Table 5).

\section{DISCUSSION}

The results provide considerable information about the composition, structure and dynamics of the benthic megafauna on the southeastern Brazilian shelf. They also disclose important ecological characteristics governing the distribution of the species, besides revealing the influence of seasonal phenomena on the maintenance of the assemblages.

Principal component analysis reflected the spatial structure defined by the correlation matrix among the variables (R-mode) or among the sample unities (Qmode) (Sneath \& Sokal 1973). Flos (1979) suggested that the area sampled is homogeneous if the first main axis presents a distinctly higher value than the other axes. However, if this same universe is heterogeneous and variable, the values are more similar and the explained variance is divided among the first 3 or 4 axes. This latter situation was the case for our data, which for 1985-86 displayed $49.11 \%$ of the variance in the first 4 axes and an accentuated importance of the first 2 axes $(35.6 \%)$. Application of PCA to the 1986-87 data set supported these results, showing $54.41 \%$ of the total variance in the first 4 axes, with axes I and II accounting for $41.27 \%$.

Thus, PCA pointed out the heterogeneity of the system investigated, and the factors responsible for its structural changes. The SMLR model aided interpretation of the causes of variability.

The results suggest that the depth variation and the influence of water masses, in addition to the welldefined frontal system, are the most important agents 
Table 5. Significant relationships identified from stepwise multiple regressions between axis scores and environmental variables for 54 complete cases

\begin{tabular}{|c|c|c|c|c|c|c|c|}
\hline \multirow[b]{2}{*}{ Axis } & \multicolumn{2}{|c|}{$1985-1986$} & \multirow[b]{2}{*}{$\mathrm{p}$} & \multicolumn{4}{|c|}{$1986-1987$} \\
\hline & Variable & $t$-value & & Axis & Variable & $t$-value & $\mathrm{p}$ \\
\hline I & Intercept & -0.77 & $\cdot$ & I & Intercept & 2.11 & $\cdots$ \\
\hline I & Depth & -5.14 & $\cdots$ & I & Depth & -7.68 & $\cdots$ \\
\hline $\mathrm{I}$ & Temperature & 2.85 & $\because$ & I & Sand & -6.84 & $\cdots$ \\
\hline \multirow[t]{2}{*}{ I } & \multirow[t]{2}{*}{ Mud } & \multirow[t]{2}{*}{-1.88} & \multirow[t]{3}{*}{$\cdots$} & I & Oxygen & 3.06 & $\cdots$ \\
\hline & & & & I & Salinity & -2.01 & $\cdot$ \\
\hline I & $r^{2}$ & 0.637 & & I & $\mathrm{r}^{2}$ & 0.801 & \\
\hline II & Intercept & 1.02 & $\cdot$ & II & Intercept & -3.07 & $\cdots$ \\
\hline II & Temperature & 2.51 & $\cdots$ & II & Depth & -4.29 & $\cdots$ \\
\hline \multirow[t]{2}{*}{ II } & \multirow[t]{2}{*}{ Sand } & \multirow[t]{2}{*}{-3.47} & \multirow[t]{3}{*}{$\cdots$} & II & Mud & 2.88 & $\cdots$ \\
\hline & & & & II & Sand & 4.04 & $\cdots$ \\
\hline II & $r^{2}$ & 0.326 & & II & $\mathrm{r}^{2}$ & 0.353 & \\
\hline
\end{tabular}

Table 6. Average species diversity $\left(H^{\prime}\right)$, average evenness $(J)$ and number of samples $(n)$ for each assemblage distinguished by cluster analysis during the study period. Mann-Whitney $U$-test results are shown for mean diversity values of the 4 zones considered. CW: Coastal Water; SACW: South Atlantic Central Water

\begin{tabular}{|c|c|c|c|c|c|c|c|c|c|}
\hline \multirow{2}{*}{\multicolumn{3}{|c|}{ Groups (zones) }} & \multicolumn{3}{|c|}{$1985-1986$} & \multicolumn{4}{|c|}{$1986-1987$} \\
\hline & & & $\mathrm{n}$ & $H^{\prime}$ & $J$ & & $\mathrm{n}$ & $H^{\prime}$ & $J$ \\
\hline \multicolumn{3}{|c|}{ CW zone (I) } & 20 & 1.70 & 0.67 & & 12 & 2.05 & 0.63 \\
\hline \multicolumn{3}{|c|}{ Mixed zone with CW dominance (II) } & 15 & 1.91 & 0.76 & & 25 & 2.20 & 0.76 \\
\hline \multicolumn{3}{|c|}{ Mixed zone with SACW dominance (III) } & 12 & 0.73 & 0.36 & & 12 & 0.65 & 0.21 \\
\hline \multicolumn{3}{|c|}{ SACW zone (IV) } & 06 & 1.34 & 0.66 & & 05 & 1.62 & 0.56 \\
\hline \multirow[t]{2}{*}{ Zones } & \multicolumn{4}{|c|}{$1985-1986$} & \multicolumn{5}{|c|}{$1986-1987$} \\
\hline & $U$-test & & & Result & & $U$-test & & & Result \\
\hline III-IV & $U=11$ & & & III $<$ IV & & $U=7$ & & & III $<$ IV \\
\hline III-II & $U=1$ & & & III < II & & $z=4.25$ & & & III $<$ II \\
\hline I-II & $U=134^{\circ}$ & & & $\mathrm{I}=\mathrm{II}$ & & $z=0.56^{\circ}$ & & & $\mathrm{I}=\mathrm{II}$ \\
\hline I-IV & $U=29$ & & & $\mathrm{I}=\mathrm{IV}$ & & $U=19^{\circ}$ & & & $I=I V$ \\
\hline
\end{tabular}

responsible for the structure and maintenance of benthic megafauna dynamics in this area. The sedimentological parameters contribute, but on a secondary plane.

Depth was the main first factor shown by PCA and SMLR. There is a clear separation between places shallower than $50 \mathrm{~m}$ and those deeper than $50 \mathrm{~m}$. In the first case temperatures were $>17^{\circ} \mathrm{C}$, and in the second they were $<17^{\circ} \mathrm{C}$. These 2 domains, as stated before, are dominated by distinct water masses separated by a frontal zone. This frontal zone presents a strong gradient in temperature and salinity, and shifts its position cyclically over time. Its presence was responsible for the inclusion in the outer shelf group of few samples from the central and northern parts of the inner shelf.
Among the 3 variables most influencing axis $I$, the first 2 were related to the water masses present in the area, the colder and deeper SACW and the shallow and warmer $\mathrm{CW}$.

The seasonal entrance of SACW causes movements of water and organisms and reflects a marked change in water temperature. According to PCA and SMLR, temperature was the second main factor influencing megafauna dynamics.

In addition, both seasonal SACW penetration over the inner shelf and depth were the main factors for grouping the species and the sample units in cluster analysis. The dendrogram of sample unities (Fig. 6) revealed that each of the 4 sub-systems forming the large bottom ecosystem is governed by a distinct water 


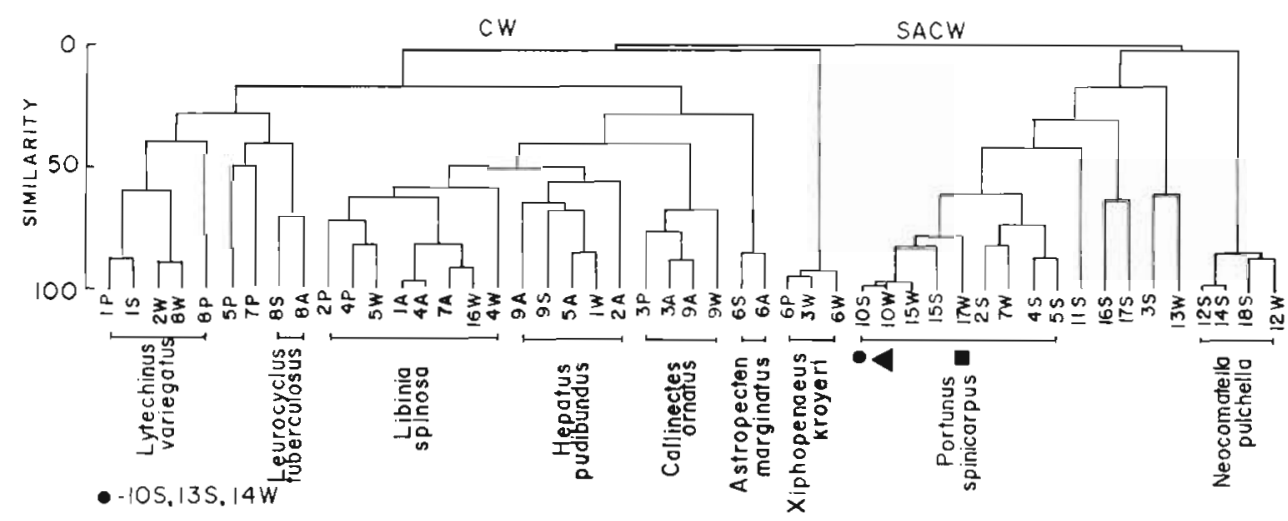

$\Delta-10 \mathrm{~W}, 11 \mathrm{~W}, 7 \mathrm{~S}$

- $-17 W, 18 W$

STATION GROUPS $1986 / 1987$

B

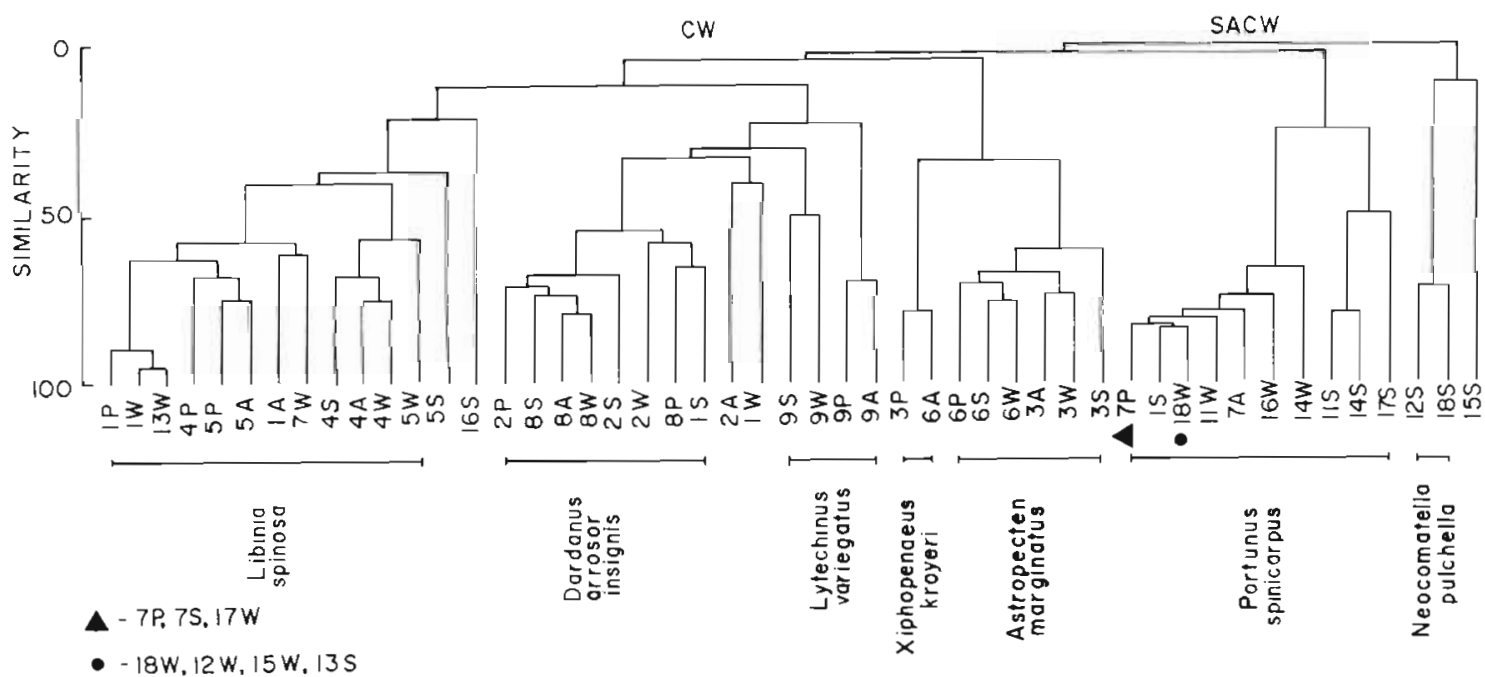

Fig. 6. Dendrograms showing groups of sample unities formed by cluster analysis (Q-mode). (A) Data from first year of study (1985-86); (B) data from second year (1986-87). A characteristic dominant species is associated with each cluster that has $>50 \%$ similarity among the stations. SACW: South Atlantic Central Water; CW: Coastal Water; P: spring; S: summer; A: autumn; W: winter

mass or by a different degree of mixing between the 2 water types.

Cluster analysis among species showed associations closely related to specific environmental conditions. Astropecten marginatus and Buccinanops gradatum were found on muddy bottoms within the shallower coastal zone, and Syllarides brasiliensis, Aphodita longicornis and Ophioplocus januarii were linked to muddy bottoms and depth around $75 \mathrm{~m}$. In contrast, some species were primarily influenced by SACW or CW water conditions. Stenocionops spinosissima and Neocomatella pulchella were found exclusively in the SACW domain; Xiphopenaeus kroyeri, Pleoticus mulleri, Penaeus schimitti and Luidia senegalensis were very numerous only in the CW. Finally, Portunus spinicarpus occurred in the coldest area of the frontal zone. In the benthic system investigated, all these species are good indicators of the presence of a specific water mass. Similarly, other authors such as Bowman (1971) and Valentin et al. (1987) have found species that indicate water-mass types in planktonic systems elsewhere.

Besides depth and water masses, another important factor responsible for megafauna structure is the northsouth geographical difference. Due to the presence of the São Sebastião Channel and the large S. Sebastião Island, as well as other islands, the southern inner shelf is more sheltered and is strongly influenced by the continent. Thus, larger amounts of fine-grained particles and organic matter are deposited on the bottom 

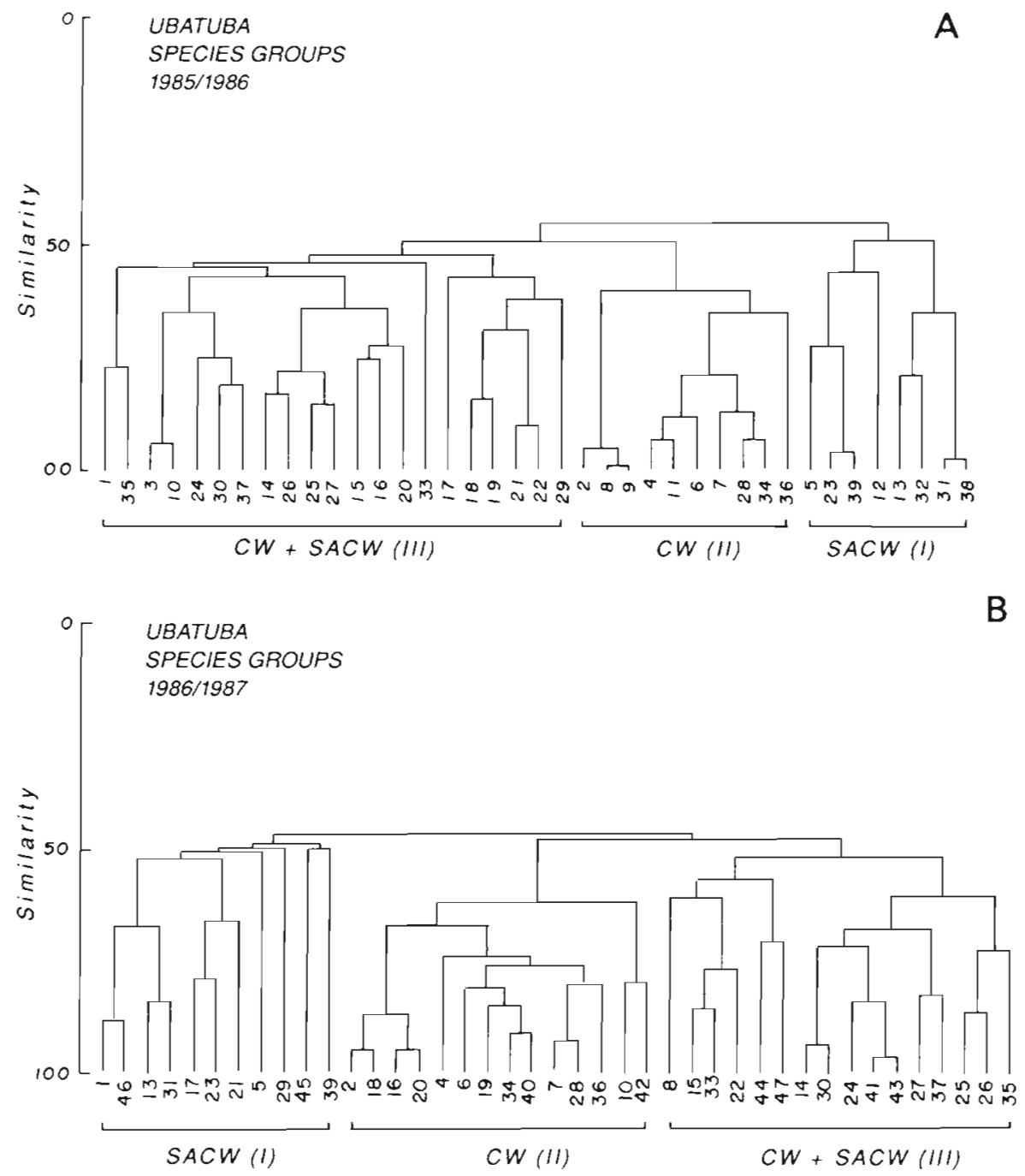

Fig. 7. Dendrograms showing species groups (I to III) formed by cluster analysis (R-mode). (A) Data from first year of study (1985-86); (B) data from second year (1986-87); SACW: South Atlantic Central Water; CW: Coastal Water. Numbers refer to species listed in Table 4 toward the south. In contrast, coarser particles settle on the northern inner shelf and in offshore areas. As a consequence of topography the hydrological characteristics of the sub-areas also differ, the northern part being directly influenced by the open sea. This habitat is under the influence of SACW most of the year. The present results also indicate a warmer situation in the southern part of the area (Fig. 3), since it is frequently filled with CW.

In addition, results on species composition, density and biomass reflect the differences existing on the inner shelf, since they present a distinct distribution in relation to distance from the coast and latitude. These data reflect higher values for the central area, followed by the southern part. So, the mid-southern and northern areas can be considered zoogeographically distinct.

The present study identified 47 dominant species in the benthic megafauna. The high number of dominant species present in the Ubatuba region suggests that it is a tropical system or a system with tropical affinities. These results, compared with those of Abelló et al. (1988), show that the Ubatuba shelf contains twice as many decapod species than the subtropical Catalan coast, when the same sampling depth range (20 to 1.00 $\mathrm{m})$ is considered.

The temporal variation in species composition, density and biomass is directly related to 2 crustacean species, Portunus spinicarpus and Xiphopenaeus kroyeri. Their presence strongly contributes to the existence and maintenance of the benthic communities, and their occurrence is linked to the different water masses present in the area.

The peaks of abundance observed for megafauna on the inner shelf during summer 1985-86 and on the outer shelf during winter $1986-87$ were due to Portunus spinicarpus. In these periods and places the cold SACW dominated. On the other hand, Xiphopenaeus kroyeri was responsible for the peaks of abundance in 
winter 1986 and autumn 1987 on the inner shelf, where Coastal Water was present in these periods. X. kroyeri enters the area as SACW retreats to the outer shelf and bottom temperature is raised to $23-25^{\circ} \mathrm{C}$. During the second year of the study SACW retreated early in autumn instead of in winter as during the first year; thus, the number of $X$. kroyeri varied accordingly.

These 2 species alternate in density and biomass dominance, following the seasonal variation of water masses. Fig. 8 illustrates the adjustments observed between these highly dominant species. Both Portunus spinicarpus and Xiphopenaeus kroyeri presented, respectively, large negative and positive loadings in PCA axis I (Fig. 5A, C). According to Cassie \& Michael (1968) this fact indicates they belong to 2 negatively correlated communities, the one tending to replace the other in space.

The number of species and their relative abundance play an important role in defining the complex interactions existing within the communities. According to Levinton (1982) species richness reflects both evolutionary and ecological processes ocurring in a community, thus mirroring its structure.

In the present study the benthic megafauna showed relatively homogeneous diversity values for the whole area, except the frontal zone. The low values found here signalise the state of disturbance characteristic of such a system. As suggested by Owen (1981), since frontal systems reflect mixing conditions due to physical processes, they can both initially determine and change patterns of biological distribution in the sea.

In this study the frontal zone presented quite low diversity and evenness values, indicating the presence of few species. Portunus spinicarpus was widely dominant here, frequently representing up to $90 \%$ of the megafauna. The null value for diversity found at Stn 13 in summer reflects the total occupation by Portunus spinicarpus of this place at that time.

The inner shelf had high diversity and evenness values. However, when invaded by the frontal system it

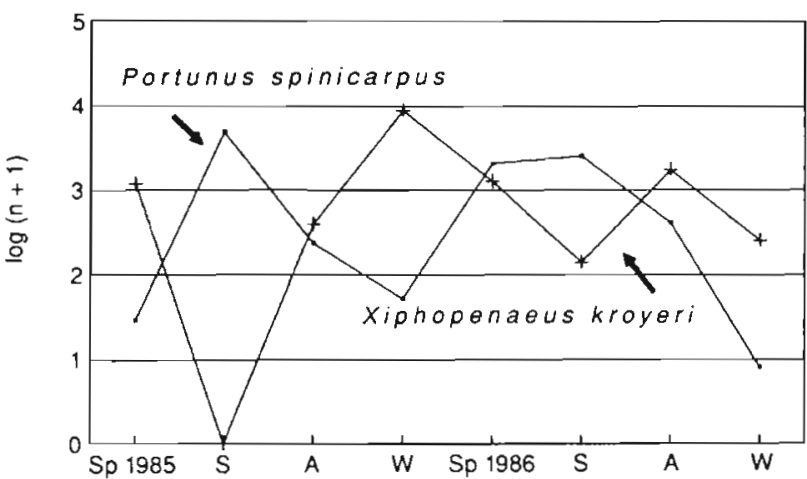

Fig. 8. Portunus spinicarpus and Xiphopenaeus kroyeri. Seasonal variation in density on the inner shelf during the study period Sp: spring; S: summer; A: autumn; W: winter undergoes an abrupt change in environmental conditions. As a result, Portunus spinicarpus is successful in dislodging other species which are very abundant there otherwise. The species discriminated against by the new frontal conditions were Callinectes ornatus at Stns 2 and 4 and Astropecten marginatus, Luidia Iudwigi scotti and Tethyaster vestitus at $\operatorname{Stn} 7_{\text {; they disap- }}$ peared from these locations, returning only after the front had retreated.

Species diversity increases again on the outer shelf, at places where SACW is always present. In addition, all the species from this zone are stenothermic, agreeing with the observations of Sanders (1968) and Bowman (1971).

The benthic megafauna from the Ubatuba region showed high stability in relation to the total number of species and individuals. The high evenness values corroborate this finding. The observed stability is unusual for coastal areas, occurring most commonly at depths over $100 \mathrm{~m}$ (Gray et al. 1985).

The general pattern of stability seems to be maintained by adjustments within the community. They occur when an increase in abundance of one species is followed by a decrease of another. These adjustments in density are due to the frontal system penetration over the shelf. The results presented here on structure and dynamics of the benthic megafauna reflect a dynamic steady state existing within the community. According to Gray et al. (1985), this stability characterizes the major part of communities from natural and undisturbed environments.

In conclusion, the continental shelf offshore of Ubatuba seems to constitute a natural environment not yet disturbed by anthropogenic action, and strongly influenced by foreseeable cyclic variations of a frontal system.

Acknowledgements. The author is grateful for financial support from the Comissão Interministerial para Recursos do Mar (CIRM) through Interdisciplinary Research Project no. 9214 Several colleagues contributed in identifying some megafauna species: Gustavo de Mello and Silvia Sartor (Brachyura); Luiz R. Tommasi and Ana M. G. Monteiro (Echinodermata): M. Iwai (Dendrobranchiata and Caridea); Paulo C. Paiva (Polychaeta); and Paulo S. Young (calcareous Anthozoa). To the students and technicians of Instituto Oceanográfico, University of Sāo Paulo, my sincere thanks for their help and constant enthusiasm in the field and laboratory work. The manuscript benefited from comments by MEPS anonymous reviewers

\section{LITERATURE CITED}

Abelló, P., Valladares, F. J., Castellón, A. (1988). Analysis of the structure of decapod crustacean assemblages off the Catalan coast (North-West Mediterranean). Mar. Biol. 98: 39-49

Bordin, G. (1987). Brachyura da plataforma continental do Rio Grande do Sul, Brasil e áreas adjacentes (Crustacea, Decapodaj. Iheringia, Ser. Zool., Porto Alegre 66: 3-32 
Bowman, T. E. (1971). The distribution of calanoid copepods of the Southeastern United States between Cape Hatteras and Southern Florida. Smithson. Contr Zool. 96: 1-58

Cassie, R. M., Michael, A. D. (1968). Fauna and sediments of an intertidal mud flat: a multivariate analysis. J. exp. mar Biol. Ecol. 2: 1-23

Castro Filho, B. M. de, Miranda, L. B. de, Miyao, S. Y. (1987). Condiçōes hidrográficas na plataforma continental ao largo de Ubatuba; variaçōes sazonais e em média escala. Bolm Inst. Oceanogr., S Paulo 35(2): 135-151

Davis, I. G. (1973). Statistics and data analysis in geology, with FORTRAN programs by Robert 1. Sampson. John Wiley, New York

Flos, J. (1979). Interpretación de varios análisis de las componentes principales aplicados a un conjunto de datos oceanográficos de una zona neritica del golfo de Vizcaya. Investigación pesq. 43(3): 611-635

Folk, R. L., Ward, W. C. (1957). Brazos River bar: a study of the significance of grain size parameters. J. sedim. Petrol. $27(1): 3-27$

Fúlfaro, V. J., Amaral, G. (1970). 'Trend Surface Analysis' das areias da praia do Tenório, Ubatuba, SP. Anais Soc. Bras. Geol. 3: $37-42$

Gray, J. S., Valderhaug, V., Ugland, K. I. (1985). The stability of a benthic community of soft sediment. In: Gibbs, P. E. (ed.) Proc. 19th Eur. Mar. Biol. Symp. Cambridge Univ. Press, Cambridge, p. 245-253

Grebmeier, J. M., Feder, H. W., McRoy, C. P. (1989). Pelagicbenthic coupling on the shelf of the Northern Bering and Chukchi Seas. II. Benthic community structure. Mar. Ecol. Prog. Ser. 51: 253-268

Grebmeier, J. M., McRoy, C. P., Feder, H. M. (1988). Pelagicbenthic coupling on the shelf of the Northern Bering and Chukchi Seas. I. Food supply source and benthic biomass. Mar. Ecol. Prog. Ser. 48: 57-67

Gross, M. G. (1971). Analysis of carbonaceous organic matter in sediments and sedimentary rocks. In: Carver, R. E. (ed.) Procedures in sedimentary petrology. Wiley-Interscience, New York, p. 573-596

Hughes, R. N., Peer, D. L., Mann, K. H. (1972). Use of multivariate analysis to identify functional components of the benthos in St. Margaret's Bay, Nova Scotia. Limnol. Oceanogr. 17(1): 111-121

Jackson, J. B. C. (1972). The ecology of the molluscs of Thalassia communities, Jamaica, West Indies. II. Molluscan population variability along an environmental stress gradient. Mar. Biol. 14(4): 304-337

Landim, P. M. B. (1988). Introduçāo à geoestatistica. Inst. Geociências e Ciências Exatas, UNESP. Publ. Didat. no. 3, São Paulo

Levinton, J. S. (1982). Marine ecology. Prentice-Hall, New Jersey

Longhurst, A. R. (1978). Ecological models in estuarine management. Ocean Management 4: 287-302

This article was submitted to the editor
Maurer, D., Leathem, W. (1980). Dominant species of polychaetous annelids of Georges Bank. Mar. Ecol. Prog. Ser. 3: 135-144

Neiva, G. de S. (1969). Observations on the shrimp fisheries of the central and southern coast of Brazil. FAO Fish. Rep. 3: $847-858$

Owen, R. W. (1981). Fronts and eddies in the sea: mechanisms, interactions and biological effects. In: Longhurst, A. R. (ed.) Analysis of marine ecosystems. Academic Press, London, p. 197-233

Petti, M. A. V. (1990). Hábitos alimentares dos crustáceos decápodos braquiúros e seu papel na rede trófica do infralitoral de Ubatuba. M.Sc. thesis, University of São Paulo

Riley, J. P. (1971). The dissolved gases in the sea water. I. Gases other than carbon dioxide. In: Riley, J. P., Chester, R. (eds.) Introduction to marine chemistry. Academic Press, London, p. 105-120

Rios, E. C. (1985). Seashells of Brazil. Fundação Universidade do Rio Grande, Rio Grande

Sanders, H. L. (1968). Marine benthic diversity: a comparative study. Am. Nat. 102: 243-282

Sartor, S. M. (1990). Composição e distribuição dos Brachyura (Crustacea, Decapoda) no Litoral Norte do Estado de São Paulo. Ph.D, dissertation, University of São Paulo

Shepard, F. P. (1954). Nomenclature based on sand-silt-clay ratios. J. sedim. Petrol. 24(3): 151-158

Siegel, S. (1956). Non-parametric statistics for the behavioral sciences. McGraw-Hill Co. and Kogakusha Co., Tokyo

Smetacek, V (1984). The supply of food to the benthos. In: Fasham, M. J. R. (ed.) Flows of energy and materials in marine ecosystems. Plenum Press, New York

Sneath, P. H. A., Sokal, R. R. (1973). Numerical taxonomy: the principles and practice of numerical classification. W. H. Freeman \& Co., San Francisco

Soberón-Chávez, G., Yáñez-Arancibia, A., Day, J. W. JI (1988). Fundamentos para un modelo ecologico prelimin de la Laguna de Terminos. In: Yanez-Arancibia, A., Day, J. W. Jr (eds.) Ecology of coastal ecosystems in the northern Gulf of Mexico. UNAM Press, Mexico DF, p. 381-414

Suguio, K. (1973). Introduçāo à sedimentologia. Edgar Blucher/EDUSP, Sào Paulo

UNESCO (1973). International Oceanographic Tables, Vol. 2. Paris

Valentin, J. L., Monteiro-Ribas, W. M., Mureb, M. A. (1987). O zooplancton das águas superficiais costeiras do litoral fluminense: anàlise multivariada. Ciênc. Cult. 39(3): 265-271

Wiebe, W. J. (1987). Nutrient pools and dynamics in tropical, marine, coastal environments, with special reference to the Caribbean and West-Pacific regions. UNESCO Rep. mar. Sci. 46: $19-42$

Williams, A. B. (1984). Shrimps, lobsters and crabs of the Atlantic coast of the eastern United States, Maine to Florida. Smithsonian Inst. Press, Washington, D.C.

Manuscript first received: August 2, 1991

Revised version accepted: July 15, 1992 